\title{
PENINGKATAN HASIL BELAJAR FISIKA SISWA KELAS XII MIA SMA NEGERI 21 BONE MELALUI PENDEKATAN PROBLEM POSSING BERPIKIR SECARA BERPASANGAN
}

\author{
KASNAWATI \\ SMAN 21 Bone \\ e-mail: watikasna1980@gmail.com
}

\begin{abstract}
ABSTRAK
Penelitian ini adalah penelitian tindakan kelas yang dilaksanakan di SMA Negeri 21 Bone dan bertujuan untuk mengetahui peningkatan hasil belajar fisika siswa dengan menggunakan pendekatan problem possing berpikir secara berpasangan. Penelitian ini menggunakan dua siklus dengan langkah-langkah untuk setiap siklus terdiri dari: perencanaan tindakan, pelaksanaan tindakan, observasi dan evaluasi, serta refleksi. Hal ini dimaksudkan agar manakala peneliti menemukan permasalahan yang perlu perbaikannya, dapat dilaksanakan pada siklus berikutnya. Subjek penelitian adalah siswa kelas XII MIA SMA Negeri 21 Bone pada tahun pelajaran 2019/2020 yang berjumlah 28 orang dengan tingkat kemampuan dan daya serap siswa yang sangat bervariasi. Materi yang disajikan pada Siklus I yaitu Dinamika Rotasi dan Siklus II yaitu materi Keseimbangan Benda Tegar. Pengambilan data dilakukan dengan menggunakan tes hasil belajar dalam bentuk essay. Data yang terkumpul dianalisis dengan menggunakan analisis kuantitatif dan kualitatif. Di samping itu, untuk mengetahui keaktifan siswa dalam proses pembelajaran dengan pendekatan problem possing berpikir secara berpasangan digunakan lembar observasi selama kegiatan belajar mengajar berlangsung. Hasil penelitian menunjukkan bahwa: (a) setelah diberikan tindakan dengan pendekatan problem possing berpikir secara berpasangan terjadi peningkatan skor rata-rata hasil hasil belajar fisika siswa Kelas XII MIA SMA Negeri 21 Bone yang pada akhir Siklus I sebesar 70,50 menjadi 81,57 pada akhir Siklus II; (b) setelah diberikan tindakan dengan pendekatan problem possing berpikir secara berpasangan terjadi peningkatan ketuntasan belajar Kelas XII MIA SMA Negeri 21 Bone yang pada akhir Siklus I sebesar 57,14\% menjadi 85,71 \% pada akhir Siklus II; (c) terjadi peningkatan keaktifan belajar siswa dalam proses pembelajaran dari Siklus I ke Siklus II; dan (d) berdasarkan kategori standar, perolehan skor hasil belajar fisika dikategorikan tinggi. Dari hasil di atas dapat disimpulkan bahwa problem possing berpikir secara berpasangan dapat meningkatkan hasil belajar fisika siswa Kelas XII MIA SMA Negeri 21 Bone.
\end{abstract}

Kata Kunci: problem possing berpikir secara berpasangan, hasil belajar fisika, keaktifan siswa

\section{PENDAHULUAN}

Perkembangan ilmu pengetahuan dan teknologi telah membawa perubahan di hampir semua aspek kehidupan manusia dimana berbagai permasalahan dapat dapat dipecahkan dengan upaya penguasaan dan peningkatan ilmu pengetahuan dan teknologi. Selain manfaat bagi kehidupan manusia disatu sisi juga telah membawa manusia kedalam era persaingan global yang semakin ketat. Agar mampu berperan dalam persaingan global, maka sebagai bangsa perlu terus mengembangkan dan meningkatkan kualitas sumber daya manusianya. Oleh karena itu peningkatan kualitas sumber daya manusia merupakan kenyataan yang harus dilakukan secara terencana, terarah, intensif, efektif, efisien dalam proses pembangunan kalau tidak ingin bangsa kalah bersaing dalam menjalani era globalisasi tersebut.

Menyadari pentingnya proses peningkatan kualitas sumber daya manusia, maka pemerintah bersama masyarakat sama-sama telah dan terus berupaya mewujudkan amanat tersebut melalui berbagai usaha pembangunan pendidikan yang lebih berkualitas antara lain melalui pembangunan dan perbaikan kurikulum dan sistem evaluasi, perbaikan sarana pendidikan, pengembangan dan pengadaan materi ajar, serta pelatihan guru dan tenaga kependidikan lainnya. Namun kenyataan di lapangan, upaya tersebut cenderung belum memadai dan meningkatkan kualitas pendidikan. 
Salah satu langkah yang dilakukan oleh tenaga pendidik untuk mengembangkan kualitas peserta didik yakni perbaikan tingkat penguasaan materi peserta didik dengan menerapkan berbagai model pembelajaran. Pemilihan model atau metode pembelajaran yang tepat sangat membantu keberhasilan proses belajar mengajar di kelas. Namun yang terpenting adalah menimbulkan perhatian dan motivasi siswa untuk belajar, sebab tanpa adanya perhatian dan motivasi belajar maka hasil belajar yang dicapai belum optimal. Oleh karena itu, guru mempunyai peranan yang sangat menentukan dalam mengarahkan siswa untuk mencapai tujuan yang diharapkan. Sebab gurulah yang secara langsung membimbing dan mengarahkan siswa untuk belajar melalui bahan pengajaran yang diberikan sesuai dengan metode yang sesuai.

Fisika sebagai salah satu kajian bidang dari Ilmu Pengetahuan Alam (IPA) yang mempelajari peristiwa dan gejala-gejala yang terjadi di alam semesta sehingga fisika dapat dikatakan sebagai pondasi teknologi yang cukup beralasan untuk diberikan kepada siswa sebagai bekal dalam menghadapi hidup di masa mendatang (Setiawan \& Prihandono, 2021). Sebagai bagian dari IPA maka hakikat fisika dapat ditinjau dan dipahami melalui hakikat sains yaitu proses sains dan produk sains. Produk sains dapat berupa fakta, konsep, prinsip atau hukum dan teori. Sedangkan proses sains berupa langkah-langkah yang harus ditempuh oleh para ilmuwan (saintis) untuk melakukan penyelidikan dalam rangka memperoleh penjelasan tentang gejala-gejala alam.

Adapun hakekat pembelajaran sains yaitu membantu siswa agar dapat berpikir secara independen melalui pendekatan kognitif dan konstruktivisme serta dapat memecahkan masalah-masalah sains melalui proyek dan media sains (Jannah et al., 2017). Berdasarkan hal tersebut maka dibutuhkan metode pengajaran yang mampu mengembangkan keterampilan sains dari siswa.

Salah satu pendekatan pembelajaran yang dapat diterapkan dalam melibatkan siswa secara aktif guna menunjang kelancaran proses pembelajaran adalah pendekatan problem possing berpikir secara berpasangan. Dengan pembelajaran tersebut maka akan memancing keaktifan siswa dalam proses belajar, karena siswa dituntut untuk menyelesaikan soal-soal secara berpasangan dan merubahnya soal kedalam bentuk matematis.

Pendekatan problem possing merupakan salah satu pendekatan pembelajaran yang merupakan bagian dari teori Konstruktivisme. Teori kontruktivisme menekankan bahwa pengetahuan itu adalah bentukan siswa, peran guru ditekankan sebagai fasilitator yang membantu atau memfasilitasi anak didik agar belajar sendiri membangun pengetahuan mereka. Sebagai fasilitator guru diharapkan agar bersikap dialogis, mendengarkan, memberikan kebebasan dan kesempatan kepada siswa untuk aktif belajar dan mengungkapkan gagasan dan ide mereka ((Nurfidah, 2006).

Problem possing memiliki tiga batasan pengertian yaitu (a). Perumusan ulang soal yang ada dengan perubahan agar menjadi lebih sederhana dan mudah dipahami dalam rangka memecahkan soal yang rumit, (b).Perumusan/pembentukan soal yang berkaitan dengan syaratsyarat pada soal yang telah diselesaikan dalam rangka mencari alternatif pemecahan yang lain, (c). Perumusan/pembentukan soal dari kondisi yang tersedia, baik dilakukan sebelum, ketika atau penyelesaian soal (Upu, 2003).

Problem Posing merupakan kegiatan yang mengarah pada sikap kritis dan kreatif. Sebab, dalam model pembelajaran ini mengharuskan siswa membuat pertanyaan dari informasi yang diberikan. Padahal, bertanya merupakan pangkal semua kreasi. Orang yang memiliki kemampuan berkreasi dikatakan memiliki sikap kreatif. Selain itu dengan pengajuan soal, siswa diberi kesempatan aktif secara mental, fisik, dan sosial serta memberikan kesempatan kepada siswa untuk menyelidiki dan membuat jawaban (Sembiring \& Pardosi, 2016).

Pembelajaran berpikir secara berpasangan (Khaeruddin, 2006) merupakan suatu cara yang efektif untuk mengubah diskursus dalam kelas. Strategi ini menantang siswa asumsi bahwa semua resitasi dan diskusi perlu dilakukan di dalam seting seluruh kelompok. Berpikir secara berpasangan memiliki prosedur yang ditetapkan secara eksplisit untuk memberi siswa 
waktu lebih banyak untuk berpikir, menjawab dan saling membantu satu sama lain. Pembelajaran dengan menggunakan strategi. Dengan metode ini dapat melatih siswa untuk mengungkapkan pendapat sehingga dapat mengasah kemampuan berpikirnya dan berdiskusi untuk memperoleh konsep pembelajaran/solusi dari permasalahan dengan baik.

Beberapa penelitian tentang penerapan pendekatan Problem Possing Berpikir Secara Berpasangan menyimpulkan bahwa hal tersebut dapat meningkatkan hasil belajar siswa, antara lain oleh (Afiatun \& Putra, 2015) melalui penelitian dengan judul "Implementasi Model Think Pair Share (Tps) Berbasis Problem Posing (Pp) Pada Pembelajaran Fluida Dinamis"; kemudian oleh (Rasmawan, 2012) melalui penelitian dengan judul "Penerapan Model Problem Posing Bersetting Cooperatif Tipe Think Pair Share Pada Topik Asam Basa Untuk Meningkatkan Penguasaan Konsep Mahasiswa";oleh (Setiawan \& Prihandono, 2021) dengan judul penelitian "Pengaruh Model Problem Posing Tipe Semi Terstruktur Dalam Pembelajaran Fisika Kelas Xi Ipa Di Sma Negeri 3 Jember".

Kenyataan yang dihadapi oleh peneliti selama ini di SMAN 21 Bone hasil belajar fisika siswa tergolong sangat rendah dan jarang mencapai Kriteria Ketuntasan minimal (KKM), salah satu faktor yang sering menjadi hambatan siswa yaitu kurangnya kemampuan siswa dalam memahami materi dan soal-soal yang diberikan oleh guru. Sehingga diperlukan penerapan sebuah model pembelajaran yang merangsang minat siswa untuk lebih aktif dalam pembelajaran fisika. Dengan demikian siswa mampu memahami materi pembelajaran dan diharapkan hasil belajar dapat lebih meningkat.

\section{METODE PENELITIAN}

Penelitian ini adalah penelitian tindakan kelas dengan faktor kajian peningkatan hasil belajar fisika siswa melalui pendekatan problem possing berpikir secara berpasangan. Pelaksanaannya dibagi dalam dua siklus dengan 4 (empat) tahap yaitu perencanaan, tindakan, observasi dan refleksi model Kemmis dan Taggart (Arikunto, 2013). Penelitian ini dilaksanakan pada siswa kelas XII MIA SMA Negeri 21 Bone semester genap tahun ajaran 2019/2020, dengan jumlah siswa 28 orang yang terdiri dari 12 orang siswa pria dan 16 orang siswa perempuan.

Adapun faktor-faktor yang diselidiki pada penelitian ini adalah (a) Faktor in-put, yaitu dengan melihat kesungguhan siswa (memperhatikan pelajaran dan mengerjakan pekerjaan rumah) dan keaktifan siswa (bertanya pada saat pembelajaran berlangsung, mengerjakan soal di kelas). (b) Faktor proses, yaitu dengan melihat bagaimana cara guru memberikan tugas kepada siswa berupa latihan dan mengecek pemahaman siswa mengenai materi yang telah diberikan dan memberikan pertanyaan serta adanya umpan balik agar siswa dapat mengerti dan memahami apa yang telah dipelajari, (c). Faktor out-put, yaitu dengan melihat apakah pembelajaran dengan menggunakan pendekatan problem possing berpikir secara berpasangan pada pengajaran fisika mampu meningkatkan hasil belajar fisika siswa setelah pelaksanaan tindakan.

Instrumen penelitian yang digunakan berupa tes hasil belajar fisika dalam ranah kognitif dan observasi aktivitas siswa selama proses pembelajaran berlangsung untuk setiap pertemuan. Jenis data yang dikumpulkan ada dua yaitu data kuantitatif yang diperoleh dari tes akhir setiap siklus dan data kualitatif yang diperoleh dari lembar observasi dan tanggapan siswa. Data hasil belajar diperoleh dengan memberikan tes kepada siswa, sedangkan sedangkan data mengenai perubahan sikap, kesungguhan dan keaktifan siswa dalam mengikuti kegiatan belajar mengajar diperoleh dengan cara pengamatan dan observasi.

\section{HASIL DAN PEMBAHASAN}

Hasil

Data Hasil Observasi Kegiatan dan kehadiran siswa pada saat proses belajar-mengajar dikelas dapat dilihat pada tabel berikut: 
Tabel 1. Hasil Observasi Kegiatan siswa

\begin{tabular}{|c|c|c|c|c|c|c|c|}
\hline \multirow{2}{*}{ No } & \multirow{2}{*}{ Komponen yang diamati } & \multirow{2}{*}{ Siklus } & \multicolumn{5}{|c|}{ Pertemuan } \\
\hline & & & 1 & 2 & 3 & 4 & 5 \\
\hline \multirow[t]{2}{*}{1} & \multirow{2}{*}{$\begin{array}{l}\text { Siswa yang mengajukan } \\
\text { diri untuk mengerjakan } \\
\text { soal permasalahan di papan } \\
\text { tulis. }\end{array}$} & I & 4 & 4 & 4 & 5 & \multirow{8}{*}{$\begin{array}{l}\text { Tes } \\
\text { Siklus I } \\
\text { dan } \\
\text { Tes } \\
\text { Siklus II }\end{array}$} \\
\hline & & II & 5 & 7 & 7 & 7 & \\
\hline \multirow[t]{2}{*}{2} & \multirow{2}{*}{$\begin{array}{l}\text { Siswa yang mengerjakan } \\
\text { pekerjaan rumah }\end{array}$} & I & 27 & 27 & 26 & 25 & \\
\hline & & II & 26 & 25 & 27 & 27 & \\
\hline \multirow[t]{2}{*}{3} & \multirow{2}{*}{$\begin{array}{l}\text { Siswa yang memperhatikan } \\
\text { materi pada saat } \\
\text { pembelajaran berlangsung }\end{array}$} & I & 25 & 26 & 24 & 24 & \\
\hline & & II & 26 & 25 & 27 & 27 & \\
\hline \multirow[t]{2}{*}{4} & \multirow{2}{*}{$\begin{array}{l}\text { Siswa yang mengajukan } \\
\text { pertanyaa pada saat } \\
\text { pembelajaran berlangsung. }\end{array}$} & I & 6 & 6 & 7 & 7 & \\
\hline & & II & 9 & 7 & 9 & 9 & \\
\hline
\end{tabular}

Tabel 2. Data Hasil Observasi Kehadiran Siswa

\begin{tabular}{llclllll}
\hline \multirow{2}{*}{ No } & \multirow{2}{*}{$\begin{array}{c}\text { Komponen yang } \\
\text { diamati }\end{array}$} & \multirow{2}{*}{ Siklus } & \multicolumn{6}{c}{ Pertemuan } \\
\cline { 4 - 8 } & & & 1 & 2 & 3 & 4 & 5 \\
\hline \multirow{2}{*}{1} & Hadir & I & 27 & 27 & 26 & 25 & 28 \\
& Tidak Hadir & II & 1 & 1 & 2 & 3 & - \\
\hline \multirow{2}{*}{2} & Hadir & I & 26 & 25 & 27 & 27 & 28 \\
& Tidak Hadir & II & 2 & 3 & 1 & 1 & - \\
\hline
\end{tabular}

Sedangkan hasil belajar siswa yang diperoleh dari hasil siklus 1 dan 2 dapat dilihat pada tabel berikut:

Tabel 3. Distribusi Frekuensi dan Persentase Skor Hasil Belajar Siswa

\begin{tabular}{ccccccc}
\hline \multirow{2}{*}{ No } & \multirow{2}{*}{ Skor } & \multirow{2}{*}{ Kategori } & \multicolumn{2}{c}{ Frekuensi } & \multicolumn{2}{c}{ Persentase } \\
\cline { 3 - 6 } & & & Siklus I & Siklus II & Siklus I & Siklus II \\
\hline 1 & $0-39$ & Sangat rendah & 0 & 0 & $0 \%$ & $0 \%$ \\
2 & $40-59$ & rendah & 4 & 0 & $14,29 \%$ & $0 \%$ \\
3 & $60-69$ & Sedang & 8 & 4 & $28,57 \%$ & $14 \%$ \\
4 & $70-84$ & Tinggi & 15 & 21 & $53,57 \%$ & $75 \%$ \\
5 & $85-100$ & Sangat tinggi & 1 & 3 & $3,57 \%$ & $11 \%$ \\
\hline & & 28 & 28 & $100 \%$ & $100 \%$ \\
\hline
\end{tabular}


Secara umum gambaran hasil belajar siswa kelas XII MIA SMA Negeri 21 Bone ditampilkan pada grafik berikut:

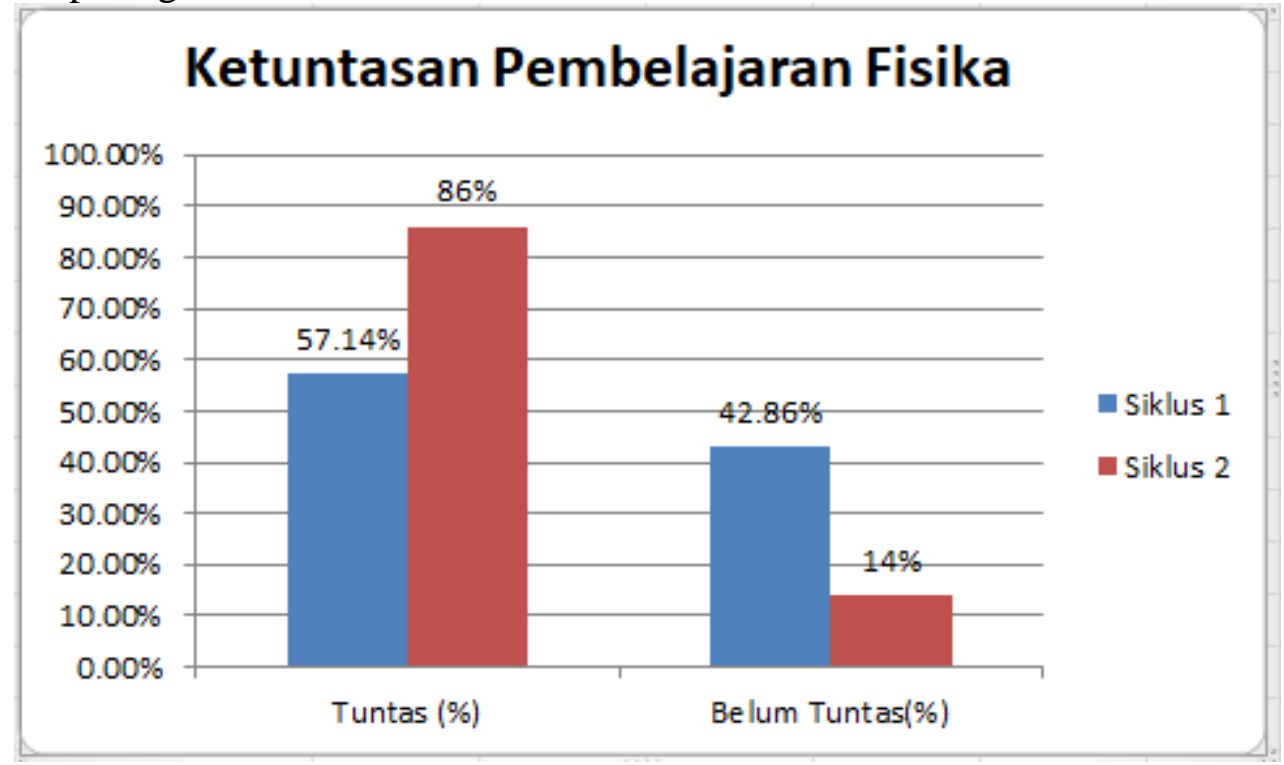

Gambar 1. Grafik Ketuntasan pembelajaran Fisika

\section{Pembahasan}

Berdasarkan hasil observasi kegiatan siswa dalam pembelajaran selama siklus I dan II terjadi beberapa perubahan keaktifan dan kemandirian siswa dalam pembelajaran. Hal ini disebabkan siswa sebagai subyek yang aktif, bukan hanya menerima langsung materi dari seorang guru. Namun dalam hal ini siswa diberikan kesempatan yang seluas-luasnya untuk mengembangkan kemampuan berpikirnya yang dituangkan dalam bentuk menyusun soal sekaligus mampu untuk menyelesaikan soal.

Pada siklus I terdapat beberapa kendala yang dihadapi antara lain siswa yang mengajukan diri untuk mengerjakan soal di papan tulis masih kurang tetapi mereka berusaha dan aktif dalam menyelesaikan soal yang diberikan dengan antusias walau masih banyak yang salah. Kemampuan siswa untuk menyusun soal pada awalnya sangat rendah, hal ini terlihat dari soal-soal yang di susun oleh siswa tata bahasanya tidak terlalu bagus. Terkadang soal yang disusun oleh siswa tidak dipahami oleh temannya karena soal yang disusun tidak memiliki semua variabel yang diharuskan untuk menyusun soal. Waktu yang diperlukan untuk menyelesaikan penyusunan soal juga membutuhkan waktu yang sangat lama untuk menyelesaikan sebuah soal. Keberanian siswa mengajukan diri untuk mengerjakan soal di papan tulis, sulit dilakukan siswa karena hanya yang dominan pintar saja yang mengacungkan tangan mengerjakan soal di papan tulis, siswa yang pengetahuannya sedang dan rendah hanya diam mendengarkan karena sebagian siswa masih malu-malu tampil kedepan

Pada siklus II observasi yang dilakukan pada siswa sama dengan siklus I, akan tetapi pada siklus ini dilakukan perbaikan dari segi tata bahasa siswa agar mampu mengkoneksikan persamaan matematis ke dalam sebuah soal cerita. Hal ini bertujuan untuk memudahkan siswa dalam menyelesaikan soal-soal dan mampu untuk menganalisis semua variabel-variabel dalam sebuah persamaan dengan baik.

Keefektifan pendekatan problem posing dalam meningkatkan hasil belajar mahasiswa juga tak lepas dari kelebihan problem posing sebagai pendekatan pembelajaran yang melibatkan hitungan atau operasi matematika.Problem posing mempunyai beberapa kelebihan (Mindarta et al., 2021), antara lain: 1) memberi kesempatan kepada siswa untuk mencapai pemahaman yang lebih luas dan menganalisis secara lebih mendalam tentang suatu topik, 2) memotivasi siswa untuk belajar lebih lanjut, 3) memberi kesempatan kepada siswa untuk mengembangkan sikap kreatif, bertanggung jawab, dan berdiri sendiri; dan 4) pengetahuan 
akan lebih lama diingat siswa karena diperoleh dari hasil belajar atau hasil eksperimen yang berhubungan dengan minat mereka dan lebih terasa berguna untuk kehidupan mereka

Keberhasilan belajar mengajar tidak hanya dipengaruhi oleh guru, melainkan dipengaruhi oleh pihak lain yang terlibat dalam pembelajaran. Beberapa faktor yang berpengaruh terhadap keberhasilan belajar mengajar, yang pertama adalah karakterisitik siswa. Beranekaragamnya karakteristik siswa di dalam kelas berpengaruh terhadap penggunaan model pembelajaran yang digunakan oleh guru karena tidak semua siswa merasa senang dengan model tersebut. Faktor kedua kondisi lingkungan sosial siswa (Setiawan \& Prihandono, 2021). Pelaksanaan pembelajaran dengan model problem posing berpikir secara berpasangan menuntut siswa untuk aktif dalam proses pembelajaran. Sehingga siswa benar-benar melakukan kegiatan pembelajaran dengan terlibat aktif di dalam pembelajaran. Hal tersebut membantu siswa untuk lebih memahami konsep Fisika.

\section{KESIMPULAN}

Berdasarkan hasil penelitian dapat ditarik kesimpulan sebagai berikut: 1). Pendekatan problem possing berpikir secara berpasangan dapat meningkatkan hasil belajar siswa baik secara individual maupun secara klasikal; 2). Pendekatan problem possing berpikir secara berpasangan akan membantu siswa untuk menyelesaikan soal secara berpasangan

\section{DAFTAR PUSTAKA}

Afiatun, U., \& Putra, N. M. D. (2015). Implementasi Model Think Pair Share (Tps) Berbasis Problem Posing $(\mathrm{Pp})$ Pada Pembelajaran Fluida Dinamis. UPEJ Unnes Physics Education Journal, 4(1), 1-5. https://doi.org/10.15294/upej.v4i1.4734

Arikunto, S. (2013). Prosedur penelitian suatu pendekatan praktik. hellis.litbang.kemkes.go.id. http://hellis.litbang.kemkes.go.id:8080/handle/123456789/62880

Jannah, S. N., Doyan, A., \& Harjono, A. (2017). Pengaruh Model Pembelajaran Kooperatif dengan Pendekatan Problem Posing Ditinjau dari Pengetahuan Awal Terhadap Kemampuan Pemecahan Masalah Fisika Siswa SMK. Jurnal Pendidikan Fisika Dan Teknologi, 1(4), 257. https://doi.org/10.29303/jpft.v1i4.268

Khaeruddin. (2006). Strategi Pembelajaran Fisika. Jurusan Fisika FMIPA UNM.

Mindarta, E. K., Sutadji, E., Irdianto, W., \& Putra, E. R. (2021). Upaya Peningkatan Hasil Belajar Fisika Teknik Dengan Pendekatan Problem Posing Melalui Kegiatan Lesson Study. Jurnal Pendidikan Teknologi Dan Kejuruan, 18(1), 1. https://doi.org/10.23887/jptk-undiksha.v18i1.26093

Nurfidah. (2006). Peranan Pembelajaran Problem Possing pada Pencapaian Hasil Belajar Fisika Kelas XI MAN Model Makassar. Universitas Negeri Makassar.

Rasmawan, R. (2012). Penerapan Model Problem Posing Bersetting Cooperatif Tipe Think Pair Share Pada Topik Asam Basa Untuk Meningkatkan Penguasaan Konsep Mahasiswa. Jurnal Pendidikan Matematika Dan IPA, 1(1). https://doi.org/10.26418/jpmipa.v1i1.165

Sembiring, Y. A., \& Pardosi, S. P. (2016). Penggunaan Model Pembelajaran Problem Posing Tipe Pre-Solution Dalam Peningkatan Hasil Belajar Fisika. Jurnal Dinamika Pendidikan, 9(1), 53. https://doi.org/10.33541/jdp.v9i1.139

Setiawan, E. N., \& Prihandono, T. (2021). Pengaruh Model Problem Posing Tipe Semi Terstruktur Dalam Pembelajaran Fisika Kelas XI IPA di SMA Negeri 3 Jember. ... Pembelajaran Fisika, 261-267. https://jurnal.unej.ac.id/index.php/JPF/article/download/23168/9316

Upu, H. (2003). Problem Posing dan Problem Solving Dalam Pembelajaran Matematika. Pustaka Ramadhan. 